\title{
Budidaya Ternak Cacing Tanah (Lumbricus rubellus) sebagai Implementasi System Zero Waste di Lingkungan Peternak Ruminansia Desa Bagorejo Jember
}

\author{
Cultivation of Earthworms (Lumbricus rubellus) as the Implementation of Zero Waste System \\ in Ruminant Farmers' Environment, Bagorejo Village, Jember
}

\author{
Gayuh Syaikhullah ${ }^{1}$, M. Adhyatma ${ }^{1}$, Satria Budi Kusuma ${ }^{1}$ \\ ${ }^{1}$ Jurusan Peternakan Politeknik Negeri Jember \\ *gayuh_syaikhullah@polije.ac.id
}

\begin{abstract}
ABSTRAK
Kelompok ternak ruminansia di Kabupaten Jember, terutama di Desa Bagorejo memiliki beberapa masalah yang perlu diselesaikan. Jumlah populasi ternak yang cukup besar membuat peternak membutuhkan solusi terkait limbah peternakan yang saat ini belum termanfaatkan dengan maksimal. Beberapa peternak sudah mencoba memanfaatkan limbah peternakan sebagai biogas dan pupuk organik. Namun efisiensi dari biogas masih terbilang sangat minim, dan pembuatan pupuk organik dirasa kurang profitable dimata peternak. Peternak ruminansia di Desa Bagorejo mengharapkan adanya solusi pemanfaatan limbah peternakan mereka yang mampu dikonversi menjadi usaha sampingan yang profitable. Tim pengabdian dari Jurusan Peternakan Politeknik Negeri Jember datang dengan membawa hasil riset terkait pemanfaatan bakteri Azotobacter Sp dalam proses pemanfaatan limbah peternakan. Pemanfaatan bakteri tersebut mampu merubah limbah peternakan menjadi media ternak cacing tanah (Lumbricus Rubellus) yang optimal. Dalam proses diseminasi ke peternak desa Bagorejo mendapatkan hasil yang cukup memuaskan. Selain pelatihan dan edukasi, kita juga melakukan mini riset di lingkungan peternak untuk meyakinkan peternak bahwa optimalisasi ternak cacing tanah bisa di bantu menggunakan kultur bakteri Azotobacter Sp. Dalam mini riset tersebut kita membuat tiga perlakuan media ternak cacing tanah, (P1) Media ternak control tanpa penambahan apapun, (P2) Media ternak dengan penambahan kultur Azotobacter Sp, dan (P3) Media ternak dengan penambahan EM4. Setiap media ternak ditabur bibit cacing sebanyak 500 gram. Setelah itu dilakukan pemeliharaan selama 4 minggu dan ditimbang hasil akhir beternak cacing tanah tersebeut. Setelah penimbangan P1 mendapatkan berat akhir 1,3kg, P2 mendapatkan berat akhir 2,4kg, dan P3 mendapat berat akhir 1,8kg. Dari hasil mini riset yang dilakukan oleh tim dan peternak harapannya mampu memberikan solusi ke peternak bahwa pemanfaatan limbah peternakan bisa menjadi media ternak cacing. Dan dengan penambahan kultur Azotobacter Sp bisa menjadikan beternak cacing tanah lebih optimal serta bisa menjadi usaha sampingan yang sustainable dan profitable.
\end{abstract}

Kata kunci - ternak cacing tanah, limbah peternakan, zero waste

\begin{abstract}
Maternal mortality rate (MMR) is one indicator to see the health status of women. The main causes of maternal death are hypertension Ruminant livestock groups in Jember Regency, especially in Bagorejo Village, have several problems that need to be resolved. A large livestock population makes breeders need a solution related to livestock waste, currently not being fully utilized. Several breeders have tried to use livestock waste as biogas and organic fertilizer. However, biogas' efficiency is still at a minimum level, and organic fertilizers' production is deemed less profitable from breeders' perspective. Ruminant breeders in Bagorejo Village expect a solution to utilizing their livestock waste which can be converted into a good side business. The community service team from the Jember State Polytechnic Animal Husbandry Department came with the results of research related to the use of Azotobacter sp bacteria in utilizing livestock waste. The utilization of these bacteria can convert livestock waste into optimal media for earthworms (Lumbricus rubellus). In the process of dissemination to farmers in Bagorejo village, the results were satisfactory. In addition to training and education, we also conduct mini-research in the breeder environment to convince farmers that the optimization of earthworm livestock can be helped by using the bacterial culture of Azotobacter sp. In this mini-research, we made three treatments for earthworm media, (P1) media without any addition, (P2) media with the addition of Azotobacter sp culture, and (P3) media with the addition of EM4. Each medium is sown with 500 grams of worm seeds. After that, maintenance is carried out for four weeks, and the final results of raising the earthworms are weighed. After weighing, $P 1$ gets a final weight of $1.3 \mathrm{~kg}, P 2$ receives a final weight of $2.4 \mathrm{~kg}$, and P3 gets a final weight of $1.8 \mathrm{~kg}$. From the results of the mini-research conducted by the team and breeders, the hope is that it will provide solutions to farmers that the use of livestock waste can be a medium for worm livestock. And with the addition of Azotobacter sp culture, it can make raising earthworms more optimal and can be a sustainable and profitable side business.
\end{abstract}

Keywords - earthworms, livestock waste, zero waste 


\section{Pendahuluan}

Kelompok ternak ruminansia di Kabupaten Jember, terutama di Desa Bagorejo memiliki beberapa masalah yang perlu diselesaikan. Jumlah populasi ternak yang cukup besar membuat peternak membutuhkan solusi terkait limbah peternakan yang saat ini belum dimanfaatkan secara maksimal. Beberapa peternak di sana sudah mencoba memanfaatkan limbah peternakan sebagai biogas dan pupuk organik. Namun efisiensi dari biogas masih terbilang sangat minim, dan pembuatan pupuk organik dirasa kurang profitable dimata peternak. Dan selain itu penumpukan limbah peternakan di sana cukup banyak sehingga jika tidak ada pengolahan / pemanfaatan lebih lanjut akan berdampak pada permasalahan sosial di lingkungan peternak. Polusi bau kotoran ternak yang cukup besar ditakutkan akan mengganggu lingkungan.

Limbah peternakan yang dihasilkan ini dari sisa metabolisme ternak ruminansia. Dalam satu hari setiap ekor sapi dewasa mampu memproduksi limbah cair sebanyak 12-15 liter dan limbah padat sebanyak $20-30 \mathrm{~kg}$. Setiap ekor domba dewasa mampu menghasilkan limbah padat kurang lebih sebanyak $1,4 \mathrm{~kg}$ dan limbah cair sebanyak 0,6-2,5 liter setiap harinya [1]. Penumpukan limbah sebanyak itu yang memicu peternak untuk segera mencari solusi pasti.

Tim Pengabdian Jurusan Peternakan Politeknik Negeri Jember mencoba memberikan solusi terkait masalah tersebut. Solusi yang diberikan merupakan pemanfaatan limbah peternakan menjadi media ternak cacing tanah (Lumbricus rubellus). Dimana saat ini pemanfaatan cacing tanah sebagai obat herbal dan bahan pembuatan kosmetik sedang naik daun. Selain itu permintaan cacing tanah sedang meningkat selama pandemi Covid-19 sebagai pakan ikan hias dan burung kicau. Selama pandemi ini banyak hobi-hobi rumahan yang sedang popular di masyarakat terutama memelihara ikan hias dan burung kicau tersebut.
Oleh sebab itu pemanfaatan limbah peternakan sebagai media beternak cacing tanah diharapkan mampu memberi solusi yang diharapkan peternak. Selain menyelesaikan masalah limbah, beternak cacing tanah bisa menjadi usaha sampingan yang sustainable dan profitable.

Tidak hanya pelatihan dan edukasi pemanfaatan limbah peternakan, tim pengabdian juga mengajak peternak untuk ikut serta dalam mini riset terkait beternak cacing tanah. Mini riset ini juga bertujuan untuk meyakinkan peternak bahwa beternak cacing tanah dengan memanfaatkan limbah peternakan bisa dioptimalkan menggunakan kultur bakteri Azotobacter Sp. Mini riset ini dilaksanakan langsung oleh peternak itu sendiri dengan pendampingan dari tim pengabdian mulai dari proses persiapan hingga evaluasi akhir.

Harapan dari tim pengabdian semua runutan kegiatan ini mampu menjadi tindakan kecil namun berdampak besar di kehidupan peternak tersebut. Dari gerakan kecil edukasi dan pelatihan ini mampu menyelesaikan masalah yang ada di lingkungan peternak terutama masalah limbah.

\section{Metodologi}

Pelaksanaan pengabdian melibatkan anggota kelompok ternak di desa Bagorejo dan Tim Pengabdian Politeknik Negeri Jember yang dilaksanakan dengan menerapkan protokol pencegahan Covid-19. Protokol pencegahan ini dilakukan dengan memakai masker, menjaga jarak, dan mencuci tangan terlebih dahulu sebelum memulai kegiatan. Lokasi pengabdian dilakukan di Desa Bagorejo, Kecamatan Gumukmas, Kabupaten Jember, Jawa Timur.

\subsection{Tahap Persiapan}

Pada tahap persiapan melakukan observasi, survey dan analisis masalah di lingkungan peternak desa Bagorejo. Skema hasil analisis masalah dapat dilihat pada Gambar 1. 


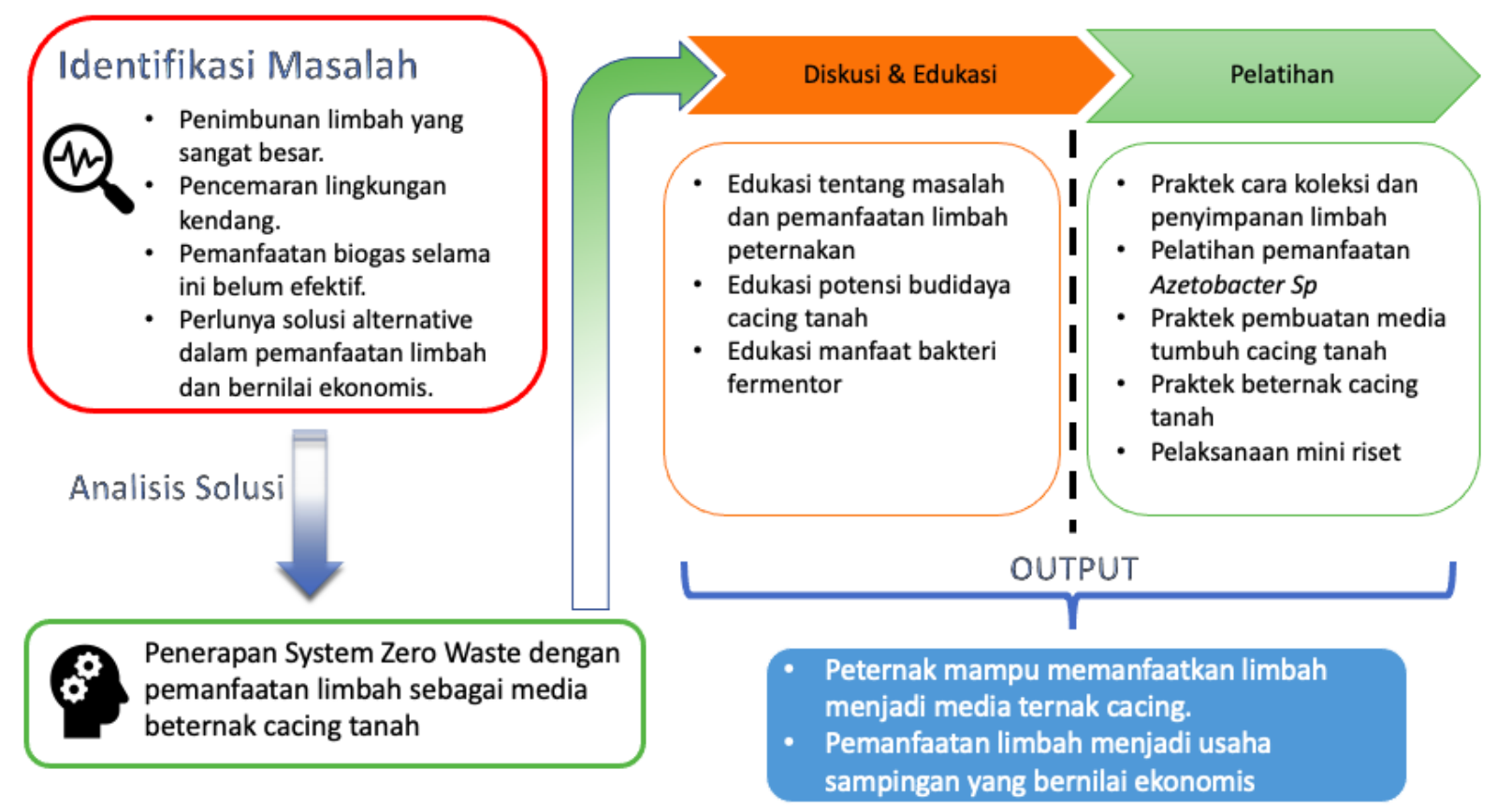

Gambar 1. Skema Analisa Permasalahan

\subsection{Tahap Pelaksanaan}

Pada tahap pelaksanaan dibagi menjadi 3 (tiga bagian), a) Pelatihan pembuatan media beternak cacing tanah, b) Pelatihan cara beternak cacing tanah, dan c) Pelaksanaan mini riset.

\subsubsection{Pelatihan Pembuatan Media Beternak}

Pelatihan ini meliputi cara mengoleksi limbah dan cara menimbun limbah sebelum dimanfaatkan atau diolah menjadi media beternak cacing. Peternak juga diberikan pengetahuan tentang pemanfaatan kultur bakteri Azotobacter sp, sebagai fermentor dalam pembuatan media ternak.

\subsubsection{Pelatihan Cara Beternak Cacing Tanah}

Dalam pelatihan ini peternak di ajak beternak secara langsung, mulai dari pembuatan biopon, perawatan hingga proses panen ternak cacing tanah.

\subsubsection{Pelaksaan Mini Riset}

Mini riset ini dilaksanakan bersamaan dengan pelatihan beternak cacing. Mini riset ini untuk menunjukkan kepada peternak fungsi pengolahan dan persiapan limbah sebelum dimanfaatkan sebagai media beternak cacing tanah.
Mini riset ini membandingkan beberapa perlakuan persiapan media ternak cacing terhadap hasil panen cacing tanah. Berikut perlakuan yang di uji coba di mini riset.

P0 : Kontrol (Limbah Tanpa Perlakuan)

P1 : Limbah + EM4

P2 : Limbah + Azotobacter $S p$

\section{Pembahasan}

Pelaksanaan pengabdian secara keseluruhan dilaksanakan selama 4 bulan dari tahap persiapan, pelaksanaan, hingga evaluasi. Seluruh rangkaian kegiatan tetap menerapkan protokol pencegahan Covid-19.

Pada tahap persiapan dilakukan survey terkait pengetahuan peternak tentang budidaya cacing tanah. Dari hasil survey menunjukkan minimnya pengetahuan peternak tentang budidaya cacing tanah. Oleh sebab itu tim memberikan edukasi secara menyeluruh tentang budidaya cacing tanah pada kegiatan utama. Selain suvey tersebut, pada tahap persiapan tim pengabdian menyampaikan rundown acara yang akan dilaksanakan bersama. Dari keseluruhan rangkaian acara yang sudah disusun untuk agenda pengabdian tersebut, pihak peternak sangat antusias dan menyetujui rangkaian acara tersebut dilaksanakan. 
Pada tahap kegiatan/pelaksanaan pengabdian, diawali dengan proses edukasi tentang pemanfaatan limbah peternakan. Dari respons peternak dari edukasi tersebut peternak lebih tertarik pembuatan media cacing tanah dikarenakan apabila limbah diolah menjadi media budidaya cacing tanah yang nantinya akan dijual sebagai tambahan pendapatan peternak khususnya di masa pandemi ini [2]. Kegiatan selanjutnya dilakukan edukasi terkait pemanfaatan bakteri Azotobacter Sp dalam proses pembuatan media ternak cacing tanah. [3] menyatakan bahwa Azotobacter sp. merupakan bakteri yang mampu mengikat nitrogen $(\mathrm{N})$. Limbah peternakan mengandung unsur hara yang cukup lengkap. Di samping mengandung unsur hara makro seperti nitrogen $(\mathrm{N})$, fosfor $(\mathrm{P})$, dan kalium $(\mathrm{K})$, pupuk kandang pun mengandung unsur mikro seperti kalsium $(\mathrm{Ca})$, magnesium (Mg), dan sulfur (S). [4] dan [5]. Dengan pemanfaatan kultur bakteri tersebut diharapkan kualitas unsur hara pada limbah peternakan semakin ideal untuk dijadikan media beternak cacing tanah.

Setelah seluruh rangkaian edukasi diberikan, peternak menerima pelatihan dan ikut serta langsung beternak cacing tanah. Tahapan praktik beternak cacing tanah ini bersamaan sekaligus dengan mini riset. Mini riset dilakukan untuk memberikan wawasan kepada peternak terkait pengaruh pemberian perlakuan pada limbah terhadap hasil panen nantinya. Pada tahap awal peternak memulai dengan membuat media beternak sesuai dengan metode mini riset. Peternak membuat 3 (tiga) jenis media ternak diantaranya, media ternak kontrol (P0), media ternak + EM4 (P1), dan media ternak + kultur bakteri Azotobacter Sp (P2). Untuk P0 limbah peternakan yang dikoleksi sebanyak $10 \mathrm{~kg}$ dan dimasukkan ke dalam tray/biopond. P1 dibuat dari $10 \mathrm{~kg}$ limbah peternakan dan ditambahkan EM4 sebanyak $100 \mathrm{ml}$, sedangkan P2 dibuat dari $10 \mathrm{~kg}$ limbah dan dicampur dengan $100 \mathrm{ml}$ kultur bakteri Azotobacter Sp.

Media tumbuh/media ternak yang telah dibuat oleh peternak selanjutnya di-resting selama 6 jam. Setelah itu ditambahkan ampas tahu dan sisa pakan ternak sebagai asupan makanan untuk cacing tanah pada fase awal pemeliharaan. Setelah itu ditambahkan indukan cacing untuk mulai diternak sebanyak 200 gram dalam setiap tray/biopond. Setelah tahap ini selesai peternak menerima pelatihan cara merawat cacing tanah. Selama pemeliharaan peternak cukup menjaga kelembapan media dan menambahkan sisa pakan ternak untuk dijadikan pakan koloni cacing tanah. Menjaga kelembapan media cacing penting untuk dilakukan agar cacing tumbuh dengan baik. Saat pembuatan vermikompos, penurunan nisbah $\mathrm{C} / \mathrm{N}$, kelembaban, temperatur dan $\mathrm{pH}$ bahan media secara periodik sangat berkaitan dengan kondisi hidup dan perkembangan cacing tanah serta indikasi terjadinya proses pengomposan [6[. Pemanenan cacing bisa dilakukan 4 minggu setelahnya.

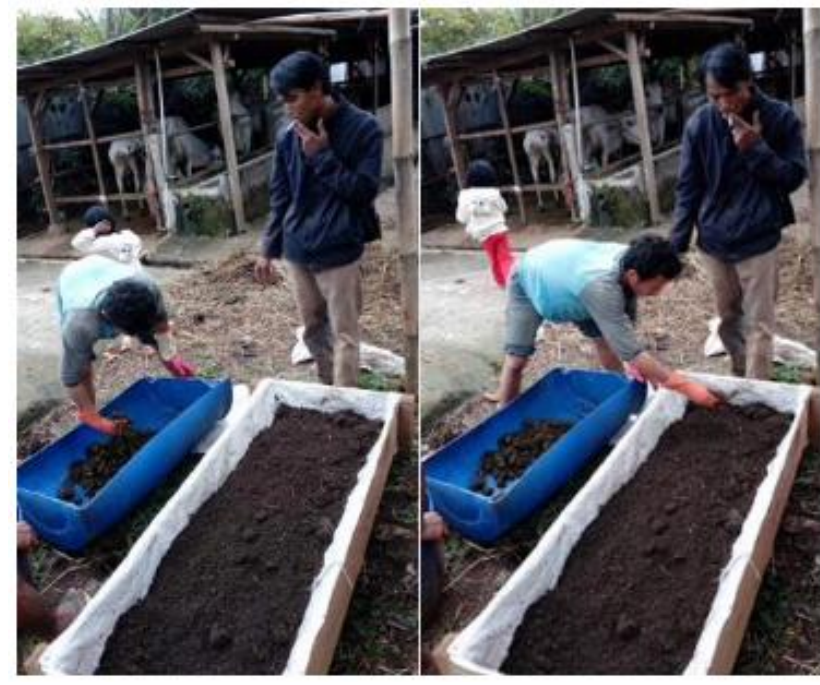

Gambar 2. Pembuatan media ternak cacing tanah

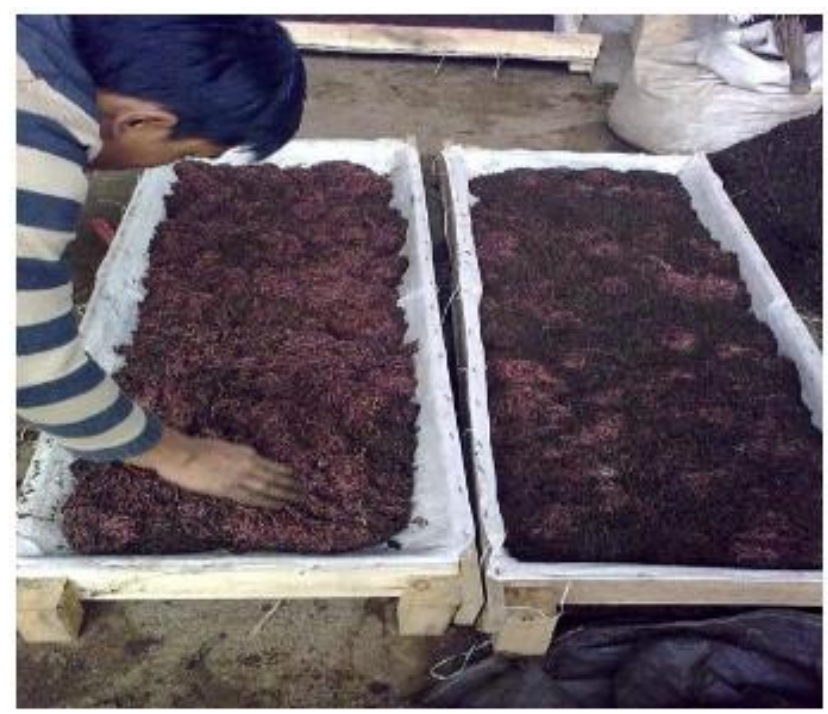

Gambar 3. Proses panen cacing tanah 
Selama pemeliharaan, peternak mengambil data perkembangan setiap minggu. Setiap minggu peternak menimbang pertambahan berat isi biopond/tray. Setelah 4 (empat) minggu pemeliharaan, dilakukan proses panen dari semua biopond mini riset. Tim pengabdian tetap mendampingi ditahap panen serta memberikan edukasi dari hasil evaluasi pemanenan. Data hasil pengamatan ternak cacing dapat dilihat pada gambar 4.

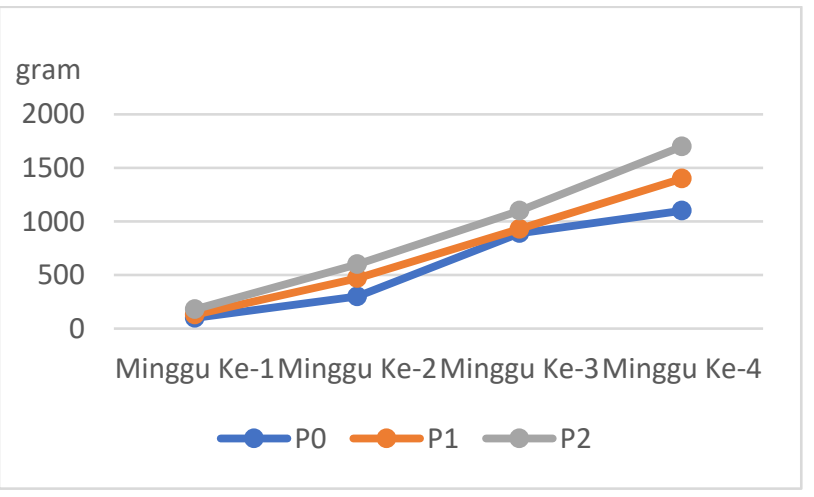

Gambar 4. Data pertambahan bobot tray/biopond

Dari hasil pengamatan peternak setiap minggu, peternak bisa mengetahui perlakuan pada limbah dapat memicu pertambahan koloni cacing tanah. Dari data di atas dapat dilihat bahwa P2 memiliki pertambahan bobot yang cukup signifikan dibanding $\mathrm{P} 0$ dan $\mathrm{P} 1$. Penambahan kultur bakteri Azotobacter pada kotoran ternak dapat meningkatkan kualitas media dan produktivitas cacing tanah dengan memenuhi kebutuhan cacing untuk bertelur dan menambah bobot badan cacing tanah [7]. Azotobacter juga dapat meningkatkan N-total pada kascing karena adanya Azotobacter dalam tubuh cacing cacing tanah yang dapat mengikat $\mathrm{N}$ yang bebas yang ada di udara [8]. Azotobakter merupakan bakteri rizobakter yang telah dikenal sebagai agen biologis pemfiksasi N2, yang menkonversi dinitrogen ke amonium melalui reduksi elektron dan protonasi dinitrogen [9]. Data pengamatan peternak setiap minggu masih perlu divalidasi dengan data hasil panen cacing tanah, karena penimbangan pertambahan bobot tersebut hanya berdasarkan bobot total isi biopond. Dengan melihat hasil panen atau bobot cacing bersih di akhir pemeliharaan, kita dapat menyimpulkan dengan pasti pengaruh perlakuan pada media ternak. Hasil panen akhir pemeliharaan dapat dilihat pada gambar 5 .

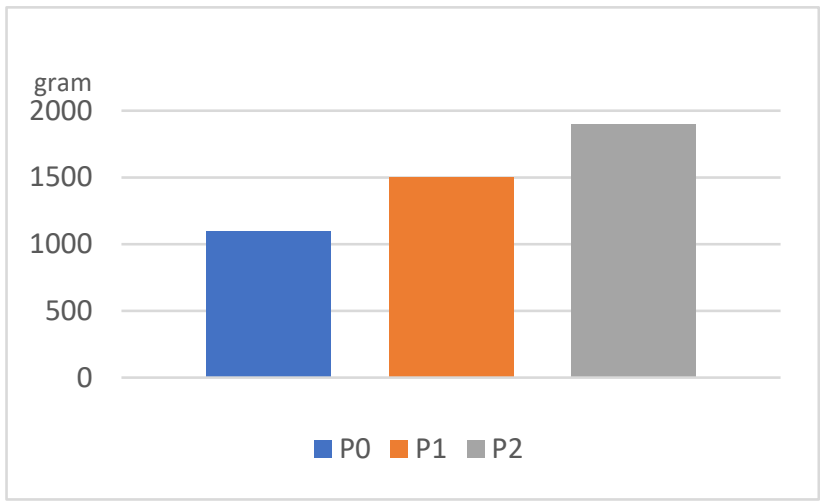

Gambar 5. Data hasil panen cacing tanah

Dari hasil panen yang sudah dilakukan oleh peternak langsung menunjukkan bahwa hasil panen cukup memuaskan dimana dari bibit 200 gram dan dipelihara selama 4 minggu dapat menghasilkan 5-10 kali lipat cacing tanah. Terutama pada perlakuan P2 dimana cukup signifikan dengan hasil panen hamper menyentuh angka 2 (dua) kilogram. Namun ke depan masih perlu pendampingan berkala dalam proses pemeliharaan cacing tanah dalam skala besar. Mungkin ke depan perlu inovasi dan riset lebih mendalam dalam budidaya cacing tanah yang lebih serius dan dalam skala besar.

Dari mini riset ini peternak dapat menyimpulkan bahwa perlakuan persiapan media ternak sangat membantu untuk optimalisasi hasil panen. Azotobakter dan Lumbricus rubellus sebagai dekomposer berperan penting dalam menjaga kestabilan tingkat kesuburan media [10]. Harapannya hal ini mampu menstimulus rasa ingin tahu peternak dan mulai untuk mencoba melakukan mini riset versi mereka sendiri untuk optimalisasi budidaya beternak cacing tanah kedepannya. Dan dari sini juga diharapkan bahwa peternak dapat lebih serius mengembangkan budidaya ternak cacing tanah ini sebagai solusi limbah yang ada di lingkungan mereka. Selain menyelesaikan masalah limbah, semoga solusi ini juga mampu memberikan potensi usaha sampingan yang profitable dan sustainable bagi peternak itu sendiri. 


\section{Kesimpulan}

\subsection{Simpulan}

Dalam proses pengabdian ini peternak sangat antusias karena mereka benar-benar melaksanakan sendiri budidaya cacing tanah tersebut. Bahkan setelah mereka melakukan mini riset tersebut, hasil yang mereka dapatkan cukup memuaskan. Hal ini memicu semangat dari peternak untuk lebih serius mendalami budidaya cacing tanah. Tim pengabdian berharap ini semua mampu memberikan jawaban atas permasalahan limbah yang ada dilingkungan peternak.

Namun dari semua hasil pengabdian ini, masih perlu dilakukan pendampingan berkala untuk peternak yang melakukan budidaya ini dalam skala besar. Dan juga perlunya tambahan informasi berkelanjutan terkait inovasi dan teknologi mengenai budidaya cacing itu sendiri.

\subsection{Saran}

Kapasitas produksi yang relatif masih kecil, pemasaran hasil panen budidaya cacing tanah tersebut disarankan ke pencinta ikan hias dan burung. Peternak sangat berharap kepedulian akademisi untuk mendampingi peternak terkait kegiatan beternak cacing. Mereka berharap akademisi juga mampu memberikan solusi di pemasaran jikalau kegiatan ini berhasil dan mampu berproduksi dengan skala yang lebih besar.

\section{Ucapan Terima Kasih}

Ucapan terima kasih tim ucapkan kepada seluruh masyarakat dan pihak yang sudah membantu suksesnya kegiatan pengabdian ini berjalan dengan sukses. Dan tak lupa ucapan terima kasih untuk pemberi dana PNBP Politeknik Negeri Jember yang telah mendanai program pengabdian ini.

\section{Daftar Pustaka}

[1] S. Rahayu, "Pemanfaatan Kotoran Ternak Sapi Sebagai Sumber Energi Alternatif Ramah Lingkungan Beserta Aspek Sosio Kulturalnya," Inotek, vol. 13, no. 2, pp. 150-160, 2009.

[2] G. Syaikhullah, M. Adhyatma, SB. Kusuma, "Implementasi Program Zero Waste dengan Pemanfaatan Bakteri Azotobacter Sp Guna Meningkatkan Pendapatan pada Kelompok Ternak
Bago Mulya di Tengah Pandemi Covid-19”. Pengabdian Masyarakat: Polije Proceedings Series, 93-97, 2020.

[3] H. B. Santoso, Pupuk Organik. Yogyakarta: Kanisius, 1998.

[4] B. R. Baral and P. Adhikari, "Effect of Azotobacter on Growth and Yield of Maize," SAARC J. Agric., vol. 11, no. 2, pp. 141-147, 2014, doi: 10.3329/sja.v11i2.18409

[5] L. Zea, N. W. Rachmadhani, D. Hariyono, and M. Santosa, "Efisiensi Pemupukan Urea pada Tanaman Jagung," vol. 18, no. 1, pp. 1-10, 2018.

[6] N. Kusumawati, "Evaluasi Perubahan Temperatur, $\mathrm{pH}$, Kelembaban Media pada Pembuatan Vermikompos dari Campuran Jerami Padi dan Kotoran Sapi Menggunakan Lumbricus rubellus" Inotek, vol. 15, no. 2, pp. 45-56, 2011.

[7] N. Cholis, E. Setyowati., dan I. W. Nursita, "Pengaruh Penambahan Kultur Azotobacter Pada Feses Kambing Terhadap Kualitas Media Dan Produktivitas Cacing Tanah (Lumbricus Rubellus)' Jurnal Ilmu-ilmu Peternakan, vol. 16, No. 2, pp. 3041, 2016.

[8] N. L. Kartini, "Pengaruh Cacing Tanah dan Jenis Media terhadap Kualitas Pupuk Organik" Pastura, Vol. 8, No. 1, pp. 49-53, 2018.

[9] Rahmi, "Kajian Efektifitas Mikroba Azotobacter sp. Sebagai Pemacu Pertumbuhan Tanaman Kakao (Theobroma cacao L)" Jurnal Galung Tropika, Vol. 3, No. 2, pp. 44-53, 2014.

[10] R. Pamungkas, Syafriadiman, H. Syawal, "Peningkatan Produktivitas Kolam Lahan Gambut melalui Teknik Biofertilizer dan Bakteri Azotobacter sp. Serta Lumbricus rubellus sebagai Organisme Dekomposer" Berkala Perikanan Terubuk, Vol. 45, No. 3, pp. 98-111, 2017. 